\title{
A Three-Dimensional, Virtual Tour of the Johnston Geology Museum
}

\author{
Marcia K. Schulmeister* and Briana Edwards, Earth Science Program, Emporia State University, Emporia, Kansas 66801, USA
}

As a need for online communication grows, digital 3D models provide an effective strategy for teaching shape- and orientation-based concepts that are essential for understanding geology. While developing our department's first, all-online section of an introductory earth-science class, we created a low-cost, 3D, virtual tour that simulates a traditional, on-campus visit to our University's geology museum. When combined with $360^{\circ}$ images, the tour allows both traditional and online museum visitors to view mineral, rock, and fossil samples on cell phones, tablets, or computers. The new approach extends the use of an established museum assignment that is regularly used in our introductory face-toface geology classes to our online students. Digital rotation and magnification of samples encourages in-depth examination of the specimens and materials that is not possible when looking through glass displays, enriching the museum experience for both online and traditional museum visitors. The new approach also provides audio tracks and alternative viewing access for differently abled or small museum patrons and expands the museum's visibility to a broader online audience.

\section{MATERIALS AND METHODS}

The Johnston Geology Museum features rocks, fossils, mining history, and Native American artifacts of relevance in Kansas. Used by both the university and a regional public audience, it has hosted thousands of open houses and school and scout field trips, in addition to supporting our earth-science curriculum. The collection is organized in display cases and as free-standing specimens that are accompanied by maps, drawings, and written explanations. We created virtual displays of ten cases using 3D modeling software (Agisoft, 2018) that aligns, masks, and renders multiple digital photos into clusters that form the basis of our models. Individual specimen models were generated from 30 to 200 digital photographs, while entire display cases required five to 10 photos, for smaller cases, and up to 150 photos for the large displays. Photos were taken at 18 megapixel resolution using a standard digital SLR camera. The rendered model files were edited and viewed using a commercially available viewer on a public-access server (Sketchfab, 2018). Threedimensional subjects can be rotated, enlarged, and navigated using a mouse or twofinger swipes on a computer, tablet, or cell phone. Software used to create the models costs US\$15 to US\$550 (depending on license type), and the $3 \mathrm{D}$ viewer may be accessed for free or at a minimal cost. Our online virtual tour can be viewed for free wherever the Internet is available.

The virtual museum exercise begins with a $360^{\circ}$ photograph of the museum. Ten "stops" (Fig. 1) along the tour include clickable links that provide access to 3D models of individual specimens, and expanded dialog boxes containing relevant background and explanations. Because most students in our introductory geology classes are not earth-science majors, and many museum visitors have minimal science background, we took advantage of an opportunity to amend the physical displays with digital materials of relevance to our exercise by adding links to new content. Additional explanations of plant and animal life modes, environmental conditions, and geologic time help to clarify concepts emphasized in our class through links to relevant short videos, location maps, and updated geologic time scales. The option of adding new questions and advanced material would allow for use of the 3D images in our upper-level geology courses. Students were able to complete the introductory virtual tour assignment in one to two hours.
OUTCOMES AND APPLICATIONS

After two semesters of its use, we have observed several positive outcomes and one limitation of the virtual experience. Online students scored higher than traditional students on exercise questions about fossil preservation and life modes, probably owing to the superior viewing angles and in-depth examination of subtle details that were possible when viewing the $3 \mathrm{D}$ models. By revising the original exercise so that the oldest fossils are visited first, and embedding links to a geologic time scale at various places within the exercise, we noted more thoughtful answers to questions about important events in earth history. Links to images or videos of modern environmental analogues helped allow students who have not traveled extensively beyond the Midwestern United States to better visualize the landscapes and environments of ancient Kansas. Because our assignment features only select display cases, the discovery that takes place when casually browsing an entire museum is lost; many valuable exhibits that are not part of our tour can only be accessed through a face-to-face visit.

The use of 3D models is emerging in the growing field of online geoscience education (e.g., Brande and McDaniel, 2018; Nesbit et al., 2020). Our exercise is the first to combine a virtual museum tour with $3 \mathrm{D}$ models that illustrate the geologic history of Kansas. The tour provides access to midcontinent geologic history that may not otherwise be available to students and geologists living outside of our region. The potential use of our exercise in online secondary education teaching may help teachers communicate earth history concepts to a younger audience and inspire future earthscience majors.

To take a 3D tour of the Johnston Geology Museum visit https://sites.google.com/view/

GSA Today, v. 30, https://doi.org/10.1130/GSATG470GW.1. CC-BY-NC.

*Corresponding author: mschulme@ku.edu; now at Department of Geology, University of Kansas, Lawrence, Kansas 66045, USA 

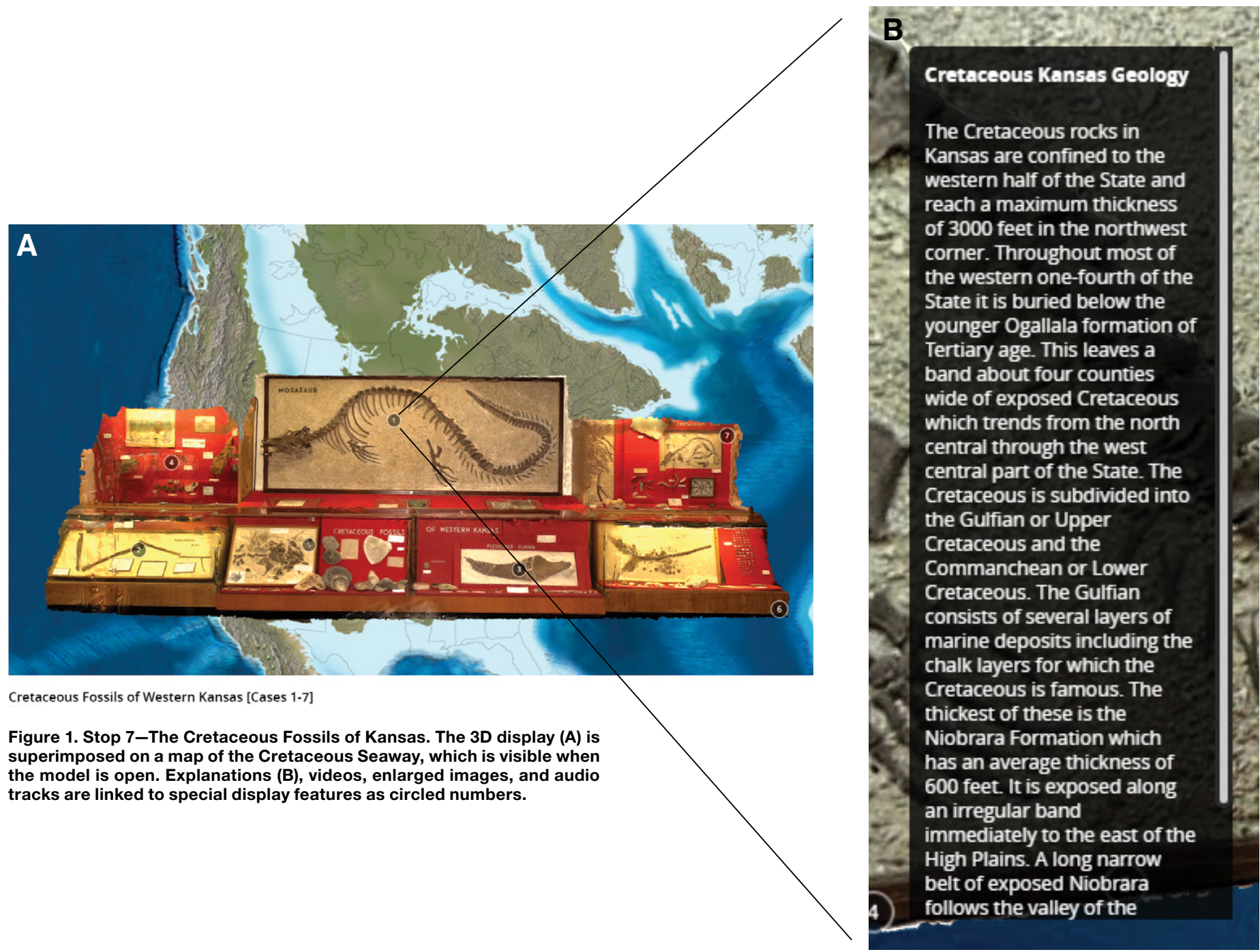

schulmeister-hydrogeology/virtual-tour-ofthe-johnston-geology-museum, or scan the QR code provided below.

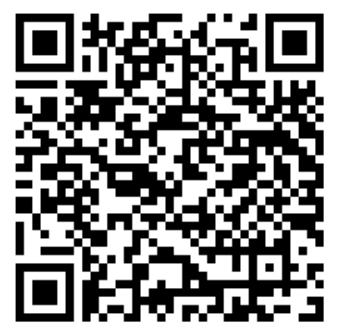

\section{REFERENCES CITED}

Agisoft LLC, 2018, Agisoft Photoscan: Petersburg, Russia, http://www.agisoft.com (accessed 14 Sept. 2020).

Brande, S., and McDaniel, P., 2018, Towards Development and Online Deployment of Virtual Rocks and Minerals for Teaching and Learning [abstract]: 16-20 July, Lawrence, Kansas, Earth Science Educators Rendezvous.
Nesbit, P.R., Boulding, A.D., Hugenholtz, C.D., Durkin, P.R., and Hubbard, S.M., 2020, Visualization and sharing of 3D digital outcrop models to promote open science: GSA Today, v. 30, p. 4-10, https://doi.org/10.1130/GSATG425A.1. SketchFab, 2018, Software: New York, New York, USA, https://sketchfab.com (accessed 14 Sept. 2020).

ManusCript ReCeived 5 June 2020

ManusCript ACCePted 10 SePt. 2020 